\title{
DAKWAH PASCA COVID 19
}

\author{
Ahmad Taufik
}

STAI Bumi Silampari Lubuklinggau ahmadtaufik201902@gmail.com

\begin{tabular}{ll}
\hline & Abstrak \\
\hline Article History & In preaching, there are important \\
Received : 17-11-2020 & things which are also factors of success \\
Revised : 14-12-2020 & or failure of preaching, namely \\
Accepted:19-12-2020 & motivation. Motivation is important \\
\hline Keywords: & and the subject of everything. In \\
Da'wah, Motivation, & motivation, it contains three main \\
Individual & components, namely moving, directing \\
& and supporting human behavior. In \\
& other words, motivation directs \\
& individual behavior towards a goal to \\
& maintain and support the behavior, \\
& while the environment must strengthen \\
& the intensity and direction of individual \\
& encouragement.
\end{tabular}

\section{Pendahuluan}

Sebagai muslim hakiki harus dapat menjalin keakraban dengan beberapa manusia menjaga komunikasi saat hidup di dunia (Ahmad Taufik, Khabar: Juni 2020). Dalam menjalani rutinitas kehidupan manusia memerlukan suatu dorongan agar bisa bertindak atau berbuat (motivasi). Sumber semangat manusia dapat berasal dari dalam pribadi masing-masing ataupun lingkungan sekitar yang sangat disenanginya. Melalui pribadi mandiri akan dapat menghela segala rintangan agar bisa diwujudkan sesuai cita-cita yang diinginkan (Muhammad Mansyur Amin, 2007: 38). Apa saja yang dianggap negatif dalam pandangan kita kalau manusia sigap dengan keyakinankeyakinan abadi akan muncul sikap semangat semua awalnya dengan perilaku "baik". Dalam hidup manusia mengenal motivasi-motivasi difungsikan tujuan antar manusia pasti berbeda (Samsul Amin Munir, 2009: 34). Dalam cakupan motivasi berprestasi adalah bagian motivasi yang menjadi topik utamanya. 


\section{Metode Penelitian}

Penulis melakukan penelitian dengan penelitian kualitatif diproses analisis dokumen data. Kajian dokumen dianggap sebagai analisis dokumen, yang terdiri buku, artikel-artikel, internet dan bahan-bahan yang sesuai dengan penelitian. Adapun cara-cara dalam pengumpulan datanya. Pertama, melalui kajian kepustakaan yang sesuai dengan bahan yang akan diteliti. Kedua, setelah data-data telah diperoleh oleh peneliti, maka selanjutnya menganalisis datanya melalui metode deskriptif sesuai dengan pemahaman penulis dalam melakukan kajian ini.

\section{Pembahasan}

Definisi Motivasi

Orang yang kurang percaya diri saat menyampaikan pendapat atau ide-ide diidentifikasi dalam berprilaku. Orang dalam menjalankan aktivitas realita motivasi-motivasi diangan-angan manusia akibat dorongan kuat (Abdul Basit, 2005: 15). Alasan atau dorongan bisa diupayakan dengan tujuan individu unggul ataupun masyarakat unggul (Hafi Anshar, 2013: 10). Pada diri manusia tidak dapat diindahkan mengenai dorongan-dorongan dari luar yang sangat kuat dibanding dorongan-dorongan tuntutan secara pribadi. Dorongan sesuai inisiatif diri sendiri akan dikalahkan oleh dorongan kepentingan secara kelompok. Dengan dorongan atau motivasi yang kuat apapun keinginan besar segera terwujud.

Realita manusia dalam menjalani kehidupan bisa didasarkan motivasi, adapun motivasi dilaksanakan manusia demi harapan yang baik dalam kehidupan. Ada saja alasan manusia menggapai harapan menghindari rasa sakit maupun sebaliknya. Kenikmatan semua orang dapat diperoleh melalui memiliki uang, lewat uang angan- angan apapun bisa diwujudkan. Banyak orang beranggapan jika memiliki harta atau uang banyak adalah cara baik dalam mewujudkan angan atau impian. Ada kalanya juga manusia ingin kerja keras mencari uang agar hidup nyaman, maka uang bagian cara tiap orang agar dapat meraih kenikmatan kehidupan (Khatib Kayo Pahlawan, 2007: 80).

Menurut Caplin (1993), motif diartikan kondisi tiap orang saat mengalami depresi atau kondisi ketergantungan berasal dari diri sendiri yang berfungsi mengubah, membiasakan dan prilaku tiap orang terhadap berbagai tujuan-tujuan dilaksanakan secara sadar. 
Motif juga bentuk keinginan dalam menggapai sasaran dalam diri manusia terdapat dorongan dari dalam diri individu supaya melakukan perilaku-perilaku sebagai identitas pribadi dan memahami kondisi-kondisi aspek yang ditimbulkan oleh lingkungan (Woodworth dan Marques dalam Mustaqim, 1991). Sedangkan menurut Koontz dalam Moekjizat (1984) motif bisa menimbulkan jaringan kegiatan dari internal diri seseorang sebagai cara dalam aktivitas-aktivitas positif terhadap cita maupun harapan standar tertentu (Amrullah Ahmad, 2014: 26).

Terlepas dari pengertian motif, Saerozi juga berpendapat bahwa dorongan-dorongan atau kiat rasa yang wajib diikuti tiap orang sesuai sumber kebahagiaan tertentu yang bisa dinamakan motif (Saerozi, 2013: 40). Sementara itu motivasi didefinisikan oleh MC. Donald (dalam Hamalik, 1992) muncul rangsangan agar menjadi pribadi yang baik disertai energi positif ditandai sikap afektif dan reaktif atau aksi menggapai tujuan pasti kehidupan.

Menurut Terry (dalam Moekjizat, 1984), motivasi merupakan capaian isi dari hati mengisi energi positif yang harus diikuti oleh banyak orang agar segera diwujudkan dalam langkah-langkah kongkrit. Aktivitas atau kegiatan-kegiatan yang bisa menggerakkan individu dalam melakukan perubahan yang lebih baik dalam kegiatan harian (Hasan Shaleh, 2000: 16). Menurut Chung dan Meggison adalah motivasi bagian ampuh dalam mencari celah terbaik disertai prilaku-prilaku dalam upaya usaha-usaha kongkrit seseorang dalam mengejar capaian kehidupan layak. Motivasi berkaitan erat dengan kepuasan kerja dan perform pekerjaan. Menurut Heidjrachman dan Suad Husnan adalah motivasi merupakan gejala-gejala prilaku mencoba seseorang agar dapai sesuai tujuan sasaran. (A Muis, 2001: 22).

\section{Teori-teori motivasi}

Teori Insentif: Yaitu teori yang mengenai cara individual mau bertindak atau menjalankan prilaku sehingga individual mendapatkan hasil dari tindakannya.

Misalnya, individu bisa kerja dari pagi hingga jam 17.00 WIB dia mau kerja sampai sore mau mendapatkan intensif atau gaji. Jika individu mengerti bahwasannya dapat penghargaan dari hasil kerja, maka dia pun kerja makin rajin lagi. Yang dimaksud insentif bisa 
tangible atau intangible. Bisa ditemukan bahwa penghargaan sangat ditunggu atau sebagai motivasi dalam mengerjakan tindakan.

Dorongan Bilogis: Yaitu teori yang mengenai membahas tidak berarti berkaitan masalah seksual saja bisa juga dorongan akan kebutuhan makan dan minum.

Teori Hirarki Kebutuhan: Teori ini dikenalkan oleh Maslow sehingga kita mengenal hirarki kebutuhan Maslow. Teori ini yang mengenai mulai dari kebutuhan fisiologis, kebutuhan akan keamanan, kebutuhan akan pengakuan sosial, kebutuhan penghargaan, sampai kebutuhan akan aktualisasi diri.

Takut Kehilangan vs Kepuasan: Teori ini yang mengenai mengatakan bahwa ada hal kongkrit yang menyebabkan motivasi manusia, yaitu takut kehilangan dan kebutuhan kepuasan (terpenuhinya kebutuhan). Takut kehilangan dimengerti rasa takut berkaitan hilangnya apapun yang ada atau dimiliki oleh manusia. Contohnya, manusia mau atau motivasinya ke kantor karena takut tidak dapat upah. Ada pula manusia rajin kerja mau mengjawab tantangan yang memiliki resiko, dan manusia bisa mengontrol tantangan bagian dari faktor kepuasan. Konon, rasa takut akan kehilangan lebih kuat daripada kepuasan, meskipun pada sebagian orang terjadi sebaliknya.

Kejelasan Tujuan: Teori ini yang mengenai manusia mau berprilaku jika manusia memperoleh impian yang sudah jelas. Asal munculnya teori jelasnya tujuan manusia terdapat motivasi tinggi apabila manusia memiliki tujuan yang jelas. Dari sini muncul apa yang dikatakan Goal Setting (penetapan tujuan).

\section{Definisi Motivasi Berprestasi}

Menurut Sardiman (2001:46) "prestasi ialah aktivitas dari individual disertai kontribusi faktor intrinsik maupun faktor ekstrinsik dalam proses tindakan dalam harian". Sedangkan pengertian prestasi menurut A. Tabrani (1991:22) "prestasi ialah kekuatan nyata (actual ability) dari pribadi individu dari kegiatan-kegiatan atau usaha perilaku dari kegiatan proses pembelajaran”.

Menurut kamus umum bahasa Indonesia (1996:186) "prestasi adalah hasil yang telah dicapai (dilakukan, dikerjakan dan 
sebagainya)". Sedangkan menurut W.S Winkel (1996:165) "prestasi adalah bukti usaha yang telah dicapai. Dari beberapa pendapat di atas dapat ditarik kesimpulan bahwa prestasi merupakan capaian tingkat tinggi dari hasil yang telah dicapai sebagai bukti usaha yang telah dilakukan.

Motivasi berprestasi menurut McClelland dan Atkinson (Buck, 1988) adalah penjabaran nilai tiap individu mencapai sukses dengan melakukan kompetisi seksama dengan memiliki kadar ukuran keunggulan. Standar keunggulan yang ada adalah berupa bentuk capaian dari prestasi-prestasi baik orang lain atau prestasi sendiri yang pernah diraih. Heckhausen (1967) memberi pengertian motivasi berprestasi sebagai cara individu dengan sifat karakternya selalu meningkatkan atau mempertahankan kecakapan diri setinggi mungkin dalam segala aktivitas atau kegiatan-kegiatan dengan menggunakan standar keunggulan sebagai pembanding. Standar keunggulan dapat diukur dari tingkat kesempurnaan hasil pelaksanaan tugas (berkaitan dengan capaian tugas), perbandingan dengan prestasi sendiri (berkaitan dengan capaian diri sendiri) dan perbandingan dengan orang lain (berkaitan dengan capaian orang lain).

Martaniah (1979) memberi pengertian tentang motivasi berprestasi sebagai motif yang dijalankan oleh individu-individu berpacu dengan beberapa keunggulan. Ukuran keunggulan ini dapat menggunakan capaian dirinya sendiri, orang lain dan dapat pula kesempurnaan tugas. Pengertian-pengertian tersebut memberi gambaran terkait kejadian atas pemahaman artian motivasi berprestasi dalam motif khusus dari dalam diri individu melakukan berbagai capaian standar nilai kesuksesan. Dimana nilai kesuksesan tersebut mengacu dari banyaknya peristiwa perbedaan-perbedaan dengan keberhasilan atas penyelesaian masalah yang dialami oleh individu maupun berupa keberhasilan masing-masing orang yang dianggap mengandung nilai-nilai kehormatan (Asep Muhyidin, 2012: 16).

\section{Komponen Motivasi Berprestasi Covid 19}

Motivasi berprestasi terdiri atas dorongan-dorongan yang memerlukan tenaga ataupun kekuatan yang dilaksanakan individu sesuai tujuan atau sasaran maupun tiap orang bertahan ketika menghadapi rintangan. Weiner (1972) mengemukakan bahwa 
motivasi berprestasi terdiri atas empat komponen. Pertama, senang menjalani aktivitas-aktivitas hal prestatif dan orang tersebut memiliki kadar kesesuain keberhasilan dengan kemampuan dan usaha keras. Orang akan bangga atas segala keberhasilan serta merasa puas sehingga makin aktif dalam kegiatan-kegiatan positif meningkatkan segala kemungkinan untuk bisa berprestasi. Ketika mengerjakan tugas ia lebih didorong oleh harapan untuk sukses daripada untuk menghindari gagal (Heckhausen, 1967).

Kedua, orang menghindari kegagalan disebabkan kurangnya melakukan usaha. Individu dengan motivasi berprestasi tinggi akan merasa marah pada diri sendiri dan merasa menyesal apabila prestasi yang dicapai tidak sebaik apa yang diharapkan (Madina, 1998). Ketiga, Selalu menampilkan perasaan suka bekerja keras dibanding individu lain yang mempunyai motivasi berprestasi rendah. Hal ini menjadikan ketangguhan individu dalam menjalankan tugas. Ia akan memelihara kualitas kerja yang tinggi untuk menyelesaikan tugas dengan sukses, untuk dapat mencapai prestasi terbaik yang dapat diraihnya dan mengungguli orang lain (Heckhausen, 1967). Keempat, banyak memahami satu pertimbangan dalam memilih tugas dengan tingkat kesulitan sedang, yaitu tugas yang tidak terlalu mudah tetapi juga tidak terlalu sukar. Hal ini dikarenakan orientasi motivasi berprestasi adalah adanya kesuksesan sebagai nilai prestasi, sehingga tugas yang terlalu mudah tidak bernilai tantangan dan tugas yang terlalu sulit akan sedikit memberikan kemungkinan untuk berhasil (Wahyu Ilaihi, 2010: 29).

\section{Simpulan}

Dari serangkaian penjabaran diatas kita dapat mengilhami hakikat pemahaman motivasi merupakan rangsangan cara manusia sebagai jati diri atau karakteristik individu dengan berbagai aktivitas atau pola tingkahlaku dengan sasaran-sasaran impian manusia. Gejala yang dilaksanakan dalam pola pandang baik dari luar (lingkungan) manusia atau berasal dari dalam diri manusia (alamiah) inilah makna inti dari motivasi.

Unsur-unsur macam bagian motivasi memiliki berbagai cara pandang yang unik. Dari segi datangnya ada motivasi intrinsik maupun motivasi ekstrinsik, dari segi pengaruhnya ada motivasi berprestasi, motivasi berafiliasi, motivasi berkompetisi, serta 
motivasi berkuasa. Dari segi proses perkembangannya ada muncul motivasi primer maupun motivasi sekunder.

Semua teori motivasi ada seluk kepentingan sebagai hasil dari cara olah tingkah laku berupa rangsangan diri individual. Perlu dimengerti juga berkenaan apapun niat atau angan- angan yang akan dijalani seseorang dari kerelaan dan kesadaran akan realita lingkungan harus ada rangsangan sehingga individu bisa menginterpretasikan dalam sebuah aktivitas harian dengan capaian sasaran.

Tiap individu dalam menjalankan capaian sasaran pasti ada teori motivasi yang dimengertinya. Oleh karena itu, saat individu dakwah harus ada keinginan kuat dari motivasi instrinsik dirinya, agar menguatkan intensitas dakwah, jelas makna dakwah serta meningkatkan etika dakwah. 


\section{DAFTAR PUSTAKA}

Abdullah, Dzikron. 2002. Metodologi Dakwah. Semarang: Fakultas Dakwah IAIN Walisongo.

Ahmad, Amrullah. 2014. Dakwah Islam dan Perubahan Sosial. Yogyakarta: LP2M.

Amin, Muhammad Mansyur. 2007. Dakwah Islam dan Pesan Moral. Yogyakarta: Al Amin Press.

Anshar, Hafi. 2013. Pemahaman dan Pengamalan Dakwah. Surabaya: Al-Ikhlas.

Arifin. 2011. Psikologi Dakwah. Jakarta: Bulan Bintang.

Basit, Abdul. 2005. Wacana Dakwah Kontemporer. Yogyakarta: Pustaka Pelajar Offset.

Ilaihi, Wahyu. 2010. Komunikasi Dakwah. Bandung: Remaja Rosdakarya.

Kayo Pahlawan, Khatib. 2007. Manajemen Dakwah Dari Dakwah Konvensional Menuju Dakwah Profesional. Jakarta: Amzah.

Muhyidin, Asep. Agus Ahmad Safei. 2001. Metode dan Pengembangan Dakwah. Bandung: Pustaka Setia.

Muis, A. 2001. Komunikasi Islami. Bandung: Rosda Karya.

Munir, Muhammad. 2006. Manajemen Dakwah. Jakarta: Prenada Media.

Oemar, Toha Yahya. 2007. Ilmu Dakwah. Jakarta: Widya.

Rafi'udin. 2002. Prinsip dan Strategi Dakwah. Bandung: Pustaka Setia.

Sanwar, Aminudin. 2015. Pengantar Studi Ilmu Dakwah. Semarang: Fakultas Dakwah IAIN Walisongo.

Shaleh, Abd. Rosyad. 2017. Managemen Dakwah Islam. Jakarta: Bulan Bintang.

Munir Samsul, Amin. 2009. Ilmu Dakwah. Jakarta: Amzah.

Saerozi. 2013. Ilmu Dakwah. Yogyakarta: Penerbit Ombak.

Saputra, Wahidin. 2011. Pengantar Ilmu Dakwah. Jakarta: Rajagrafindo Persada.

Shaleh, Hasan. 2000. Studi Islam dan Pengembangan Wawasan. Jakarta: Logos Wacana Ilmu.

Syukir, Asmuni. 2012. Dasar-Dasar Strategi Dakwah Islam. Surabaya: Al-Ikhlas.

Tasmara, Toto. 2017. Komunikasi Dakwah. Jakarta: Gaya Media Pratama. 
Umary, Barmawi. 2009. Langkah-Langkah Juru Dakwah. Solo: Romadhani.

Widjaja, A. W. 2008. Komunikasi dan Hubungan Masyarakat. Jakarta: Bumi Aksara.

Taufik, A. (2020). Dakwah Islamiyah Melalui Media Bahasa Arab. khabar, 2 (1), 33-41. 